\title{
Phosphates and Hydrogeno-Phosphates as Materials for Catalysts and Humidity Sensors
}

\author{
A. TADA \\ Department of Applied and Environmental Chemistry, Kitami Institute of Technology, Kitami, \\ Hokkaido, 090-8507 Japan; E-mail tada@catal.chem.kitami-it.ac.jp; Fax +81-157-24-7719
}

\begin{abstract}
Phosphates as surface-functional materials were investigated. Boron phosphate $\left(\mathrm{BPO}_{4}\right)$, which is known to be a solid acid catalyst, showed prominent activity for the oligomerization of light olefins giving a liquid fuel, although other phosphates were inactive. Its activity was enhanced by grinding before use or by adopting a new preparation method characterized by supercritical drying. As a catalyst support, $\mathrm{AlPO}_{4}$ was examined for selective catalytic reduction of $\mathrm{NO}$ in exhaust gas to $\mathrm{N}_{2}$ by hydrocarbon in the presence of excess oxygen. It was found that the activity of $\mathrm{Pt}(0.5 \mathrm{wt} \%) / \mathrm{AlPO}_{4}$ catalyst was higher than that of conventional $\mathrm{Pt}(0.5 \mathrm{wt} \%) / \mathrm{Al}_{2} \mathrm{O}_{3}$ catalyst, although $\mathrm{AlPO}_{4}$ alone was hardly inactive. Next, metal phosphates were examined as humiditysensing materials, and several new candidates including $\mathrm{Ti}\left(\mathrm{HPO}_{4}\right)_{2} \cdot \mathrm{H}_{2} \mathrm{O}$ were found. The humidity-sensing characteristics of $\mathrm{Ti}\left(\mathrm{HPO}_{4}\right)_{2} \cdot \mathrm{H}_{2} \mathrm{O}$ was considerably improved by treating with a $\mathrm{NaOH}$ solution. In addition, we found that $\mathrm{Cu}-\mathrm{P}-\mathrm{Y}$-O ceramics, which were produced by the solidstate reaction between $\mathrm{Cu}_{3}\left(\mathrm{PO}_{4}\right)_{2} \cdot 3 \mathrm{H}_{2} \mathrm{O}$ and $\mathrm{Y}_{2} \mathrm{O}_{3}$, showed good humidity-sensitive characteristics; its electric resistance decreased by three orders in magnitude as the surrounding relative humidity increased from $0 \%$ to $96 \%$.
\end{abstract}

\section{INTRODUCTION}

Phosphates are utilized for detergents, food additives, fertilizers, corrosion inhibitors, etc. as bulk materials, and for adsorbents, catalysts, chemical sensors, etc. as surface-functional materials. The interaction of some guest molecules with the surface of a host functional phosphate results in (1) adsorption on the surface, (2) activation of the adsorbed molecules, (3) chemical reaction on the surface, (4) change in electric or electronic properties of the host phosphate, etc. The present paper describes several surface-functional phosphates exemplified below.

\section{PHOSPHATES AS THE MATERIALS FOR CATALYST}

\section{Boron phosphate, $\mathrm{BPO}_{4}$, as a solid acid catalyst}

Light olefins can be converted to a liquid fuel by their oligomerization over acid catalysts. There are a number of oligomerization catalysts [1] such as liquid acids, solid phosphoric acid, clays, and silica-alumina. In 1981, one of the authors [2] has reported the potentiality of high-temperature outgassed boron phosphate catalyst. Recently, zeolites, particularly $\mathrm{H}$-Fesilicate [3] and H-Co-silicate [3] have been found to be very effective. The products of the oligomerization of light olefins depend on catalysts, reaction conditions, kind of olefins, and so on. In order to develop an effective olefin oligomerization process fitting one's purpose, it is necessary to understand comprehensively the activities and selectivities of various oligomerization catalysts. 
Boron phosphate, $\mathrm{BPO}_{4}(\mathrm{RP})$ was prepared by heating an equimolar mixture of boric acid and phosphoric acid at $40{ }^{\circ} \mathrm{C}$ in a rotary evaporator followed by drying in situ at that temperature, heating at $150{ }^{\circ} \mathrm{C}$ for $24 \mathrm{~h}$, and finally calcining at $360^{\circ} \mathrm{C}$ for $12 \mathrm{~h} \mathrm{[4].} \mathrm{Another} \mathrm{boron} \mathrm{phosphate,}$ $\mathrm{BPO}_{4}$ (SC) was prepared by adding acetic anhydride to a mixture of boric acid, phosphoric acid, acetic acid and methyl acetate [5]. The grinding of $\mathrm{BPO}_{4}$ sample was performed with a FRITSCH planetary micro mill pulverisette [6]. The oligomerization of olefins was carried out using a closed recirculation reactor (volume $=600 \mathrm{ml}$ ).

Figure 1 shows the results of propene oligomerization over $\mathrm{BPO}_{4}(\mathrm{RP})$ at $0-200^{\circ} \mathrm{C}$. The progress of the reaction is expressed as a rate of decrease in total pressure, $100 \cdot\left(\mathrm{P}_{0}-\mathrm{P}\right) / \mathrm{P}_{0}$, where $\mathrm{P}_{0}$ is the initial (total) pressure of the monomer and $\mathrm{P}$ is total pressure at any reaction time. At $0-100^{\circ} \mathrm{C}$, the activities of various catalysts for the oligomerization of propene decreased in the order, $\mathrm{BPO}_{4}$ (RP) $>\mathrm{SiO}_{2}-\mathrm{Al}_{2} \mathrm{O}_{3}>\mathrm{HY}$-zeolite $>\mathrm{H}-\mathrm{ZSM}-5, \mathrm{SO}_{4} / \mathrm{ZrO}_{2}$. Figure 2 summarizes the product distributions of propene oligomerization at $0-200{ }^{\circ} \mathrm{C}$ for $20 \mathrm{~h}$ over $\mathrm{BPO}_{4}$. At $0{ }^{\circ} \mathrm{C}$ the products were rich in relatively higher molecular weight substances such as $\mathrm{C}_{12-15}$ compounds. With a rise in temperature, the percentage of such substances decreased and that of $\mathrm{C}_{6}$ compound increased. At $100{ }^{\circ} \mathrm{C}$, both $\mathrm{C}_{8}$ and $\mathrm{C}_{9}$ were formed in abundance. Figure 3 shows the products of propene oligomerization at $50-200{ }^{\circ} \mathrm{C}$ for $20 \mathrm{~h}$ over $\mathrm{SiO}_{2}-\mathrm{Al}_{2} \mathrm{O}_{3}$. With increasing temperature, the percentages of $\mathrm{C}_{6}$ and $\mathrm{C}_{7}$ compounds increased. As can be seen in Figure 4 , the products of propene oligomerization at $150{ }^{\circ} \mathrm{C}$ over $\mathrm{HY}$ were similar to those over $\mathrm{SiO}_{2}-\mathrm{Al}_{2} \mathrm{O}_{3}$. However, at $100{ }^{\circ} \mathrm{C}, \mathrm{C}_{10-1,5}$ compounds were appreciably produced.

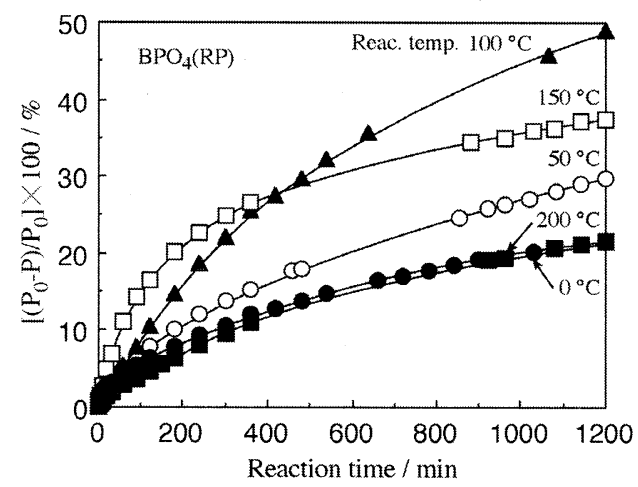

Figure 1: Oligomerization of propene over $\mathrm{BPO}_{4}(\mathrm{RP})$ at various temperatures. Initial pressure $\left(\mathrm{P}_{0}\right)$ of propene $=600$ Torr, total pressure at any time $=P$, weight of catalyst $=0.5 \mathrm{~g}$, calcination $500{ }^{\circ} \mathrm{C}, 2 \mathrm{~h}$; evacuation $500^{\circ} \mathrm{C}, 2 \mathrm{~h}$

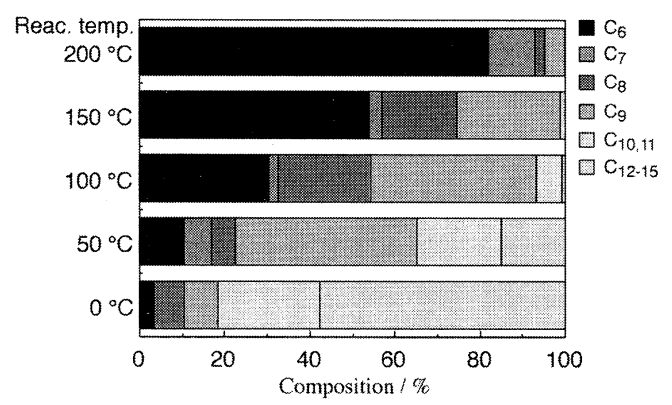

Figure 2: Products of the oligomerization of propene over $\mathrm{BPO}_{4}(\mathrm{RP})$ at various temperatures. Reac. time $=20 \mathrm{~h}$ 


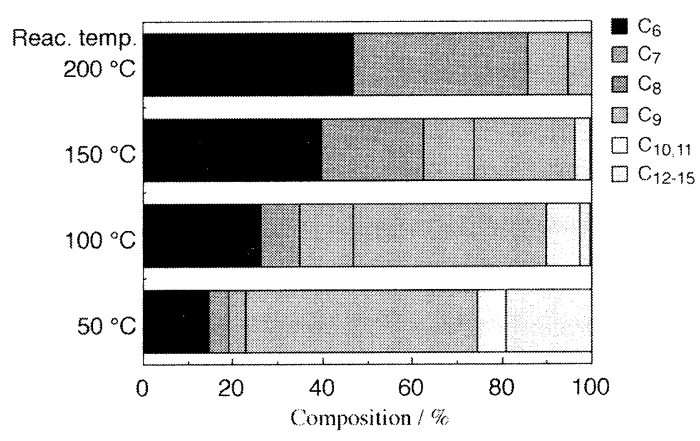

Figure 3: Products of the oligomerization of propene over silica-alumina at various temperatures. Reac. time $=20 \mathrm{~h}$

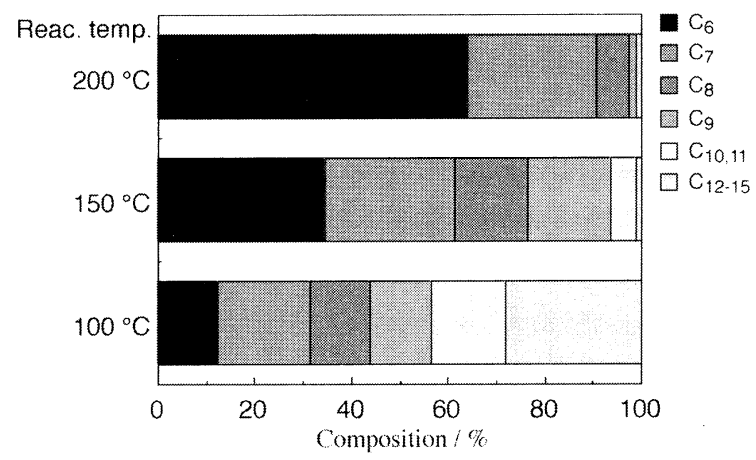

Figure 4: Products of the oligomerization of propene over HY zeolite at various temperatures. Reac. time $=20 \mathrm{~h}$

Table 1 The specific surface area and the activity of $\mathrm{BPO}_{4}(\mathrm{RP})$ for the oligomerization of $c i s$-2-butene before and after grinding

\begin{tabular}{cccccccc}
\hline \multirow{2}{*}{$\begin{array}{c}\text { Grinding } \\
\text { time } / \mathrm{h}\end{array}$} & $\begin{array}{c}\text { Surface area } \\
/ \mathrm{m}^{2} \cdot \mathrm{g}^{-1}\end{array}$ & \multicolumn{5}{c}{ Oligomerization / \% at reac. time (min) of } \\
\cline { 2 - 8 } & 15 & 6.2 & 8.6 & 10.5 & 12.9 & 14.0 & 15.9 \\
\hline 0 & 22 & 9.5 & 12.7 & 15.5 & 18.9 & 20.6 & 23.7 \\
6 & 25 & 9.2 & 12.3 & 15.1 & 18.5 & 20.2 & 23.5 \\
9 & 25 & 9.2 & 12.0 & 14.8 & 18.3 & 20.0 & 22.6 \\
12 & 27 & 8.6 & 11.6 & 14.2 & 18.3 & 20.4 & 23.4 \\
18 & 25 & 9.5 & 11.6 & 14.0 & 17.0 & 18.3 & 21.3 \\
24 & 15 & & &
\end{tabular}

Amount of cis-2-butene $=70$ Torr, $0.5 \mathrm{l}$; weight of catalyst $=0.20 \mathrm{~g}$; reac. temp. $=0{ }^{\circ} \mathrm{C}$ 
Generally the catalytic activity (per weight) of a solid catalyst depends on its specific surface area. As seen in Table 1, the specific surface area of $\mathrm{BPO}_{4}(\mathrm{RP})$ was increased by grinding it and as a result its activity for the oligomerization of cis-2-butene was also increased [6]. In order to prepare highly porous $\mathrm{BPO}_{4}$, a new preparative method has been developed. The method is characterized by both the reaction of $\mathrm{H}_{3} \mathrm{PO}_{4}$ and $\mathrm{H}_{3} \mathrm{BO}_{3}$ in a mixture of acetic acid and methyl acetate and the subsequent supercritical drying [5]. Clearly, the activity of $\mathrm{BPO}_{4}$ (SC) was much higher than that of $\mathrm{BPO}_{4}(\mathrm{RP})$ for propene oligomerization at $50{ }^{\circ} \mathrm{C}$ (Figure 5).

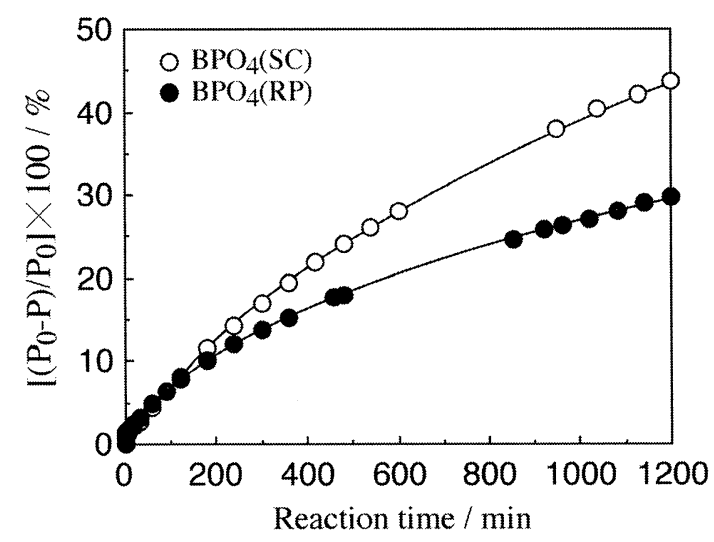

Figure 5: Oligomerization of propene over $\mathrm{BPO}_{4}(\mathrm{SC})$ and $\mathrm{BPO}_{4}(\mathrm{RP})$. Pressure of propene $=600$ Torr, weight of catalyst $=0.5 \mathrm{~g}$, calcination $500^{\circ} \mathrm{C}, 2 \mathrm{~h}$; evacuation $500^{\circ} \mathrm{C}, 2 \mathrm{~h}$; reac. temp. $=50^{\circ} \mathrm{C}$

\section{Aluminum phosphate (amorphous), $\mathrm{AlPO}_{4}$, as a catalyst support}

Selective catalytic reduction of NOx to $\mathrm{N}_{2}$ by a hydrocarbon (HC) in the presence of excess oxygen, HC-SCR, has been investigated over various catalysts such as zeolites, metal oxides, and noble metals as one of important reactions for purifying the automotive exhaust gas of a diesel engine or a lean-burn engine [7]. One of the most extensively studied metal oxides is alumina and it is often used as a metal-loaded alumina $\left(\mathrm{M} / \mathrm{Al}_{2} \mathrm{O}_{3}\right)$ [8-10]. Aluminum phosphate, however, has seldom been used as a catalyst material for HC-SCR catalysts.

Aluminum phosphate was prepared by neutralizing a solution containing an equal molar ratio of aluminum nitrate and phosphoric acid with ammonia solution [11]. Catalytic reactions were carried out with a fixed bed flow reactor by passing a reactant gas mixture at a total flow rate of $130 \mathrm{ml} \cdot \mathrm{min}^{-1}$ over a catalyst $(0.40 \mathrm{~g})$. The gas mixture contained $1000 \mathrm{ppm} \mathrm{NOx}, 2.0 \%$ $\mathrm{O}_{2}, 500$ ppm $\mathrm{C}_{2} \mathrm{H}_{4}$ or $\mathrm{C}_{3} \mathrm{H}_{6}$ as a reductant and balance helium.

Contrary to our expectation, $\mathrm{AlPO}_{4}$ alone was inactive for both $\mathrm{C}_{2} \mathrm{H}_{4}$-SCR and $\mathrm{C}_{3} \mathrm{H}_{6}$-SCR, while $\mathrm{Al}_{2} \mathrm{O}_{3}$ was considerably active. As a result of examining many metal-loaded catalysts, it was found that the activity of $\mathrm{Pt}(0.5 \mathrm{wt} \%) / \mathrm{AlPO}_{4}$ catalyst was higher than that of conventional $\mathrm{Pt}$ (0.5wt\%)/ $/ \mathrm{Al}_{2} \mathrm{O}_{3}$ catalyst for both $\mathrm{C}_{2} \mathrm{H}_{4}$-SCR and $\mathrm{C}_{3} \mathrm{H}_{6}$ - $\mathrm{SCR}$ as shown in figure $6 . \mathrm{In}_{2} \mathrm{C}_{4}-\mathrm{SCR}$, the maximal $\mathrm{NO}$ conversion value of $\mathrm{Pt}(0.5 \mathrm{wt} \%) / \mathrm{AlPO}_{4}$ is similar to that of $\mathrm{Pt}(0.5 \mathrm{wt} \%) / \mathrm{Al}_{2} \mathrm{O}_{3}$, but the temperature window of $\mathrm{Pt}(0.5 \mathrm{wt} \%) / \mathrm{AlPO}_{4}$ shifts to lower temperature by $50^{\circ} \mathrm{C}$ compared with that of $\mathrm{Pt}(0.5 \mathrm{wt} \%) / \mathrm{Al}_{2} \mathrm{O}_{3}$. The superiority in activity of $\mathrm{Pt}(0.5 \mathrm{wt} \%) / \mathrm{AlPO}_{4}$ is more evident for $\mathrm{C}_{3} \mathrm{H}_{6}-\mathrm{SCR}$. 


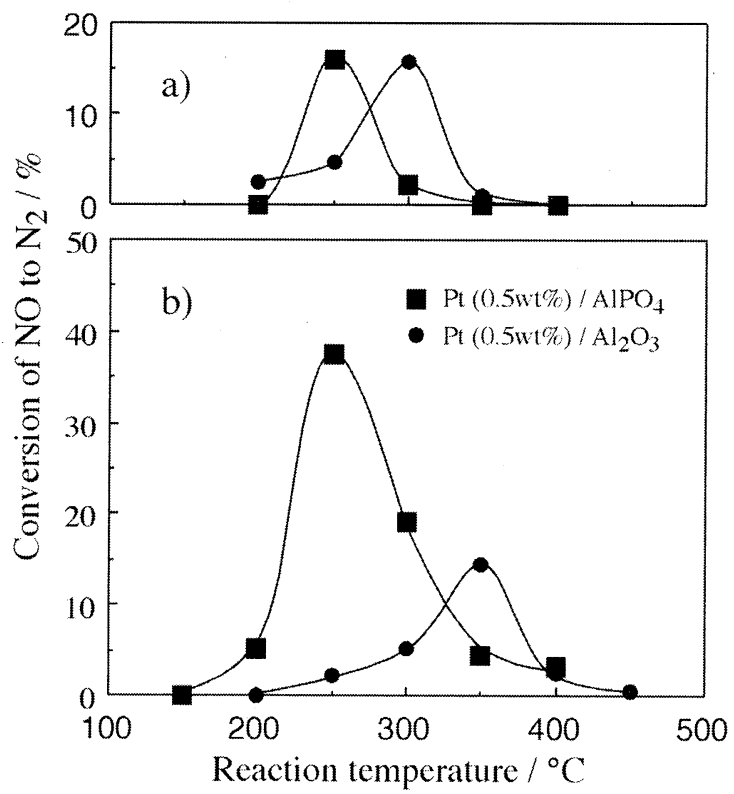

Figure 6: Temperature dependence of the catalytic activities over $\mathrm{Pt}(0.5 \mathrm{wt} \%) / \mathrm{Al}_{2} \mathrm{O}_{3}$ and $\mathrm{Pt}(0.5 \mathrm{wt} \%) /$ $\mathrm{AlPO}_{4}$. a) $\mathrm{NO}(1000 \mathrm{ppm})+\mathrm{C}_{2} \mathrm{H}_{4}(500 \mathrm{ppm})+\mathrm{O}_{2}(2 \%), \mathrm{W} / \mathrm{F}=0.18 \mathrm{~g} \cdot \mathrm{s} \cdot \mathrm{cm}^{-3}$, total flow rate $\left.=130 \mathrm{ml} \cdot \mathrm{min}^{-1} . \mathrm{b}\right)$ $\mathrm{NO}(1000 \mathrm{ppm})+\mathrm{C}_{2} \mathrm{H}_{4}(1000 \mathrm{ppm})+\mathrm{O}_{2}(5 \%), W / F=0.30 \mathrm{~g} \cdot \mathrm{s} \cdot \mathrm{cm}^{-3}$, total flow rate $=80 \mathrm{ml} \cdot \mathrm{min}^{-1}$.

\section{PHOSPHATES AS THE MATERIALS FOR CHEMICAL SENSORS}

\section{Humidity-Sensitive Characteristics of Various Metal Phosphates}

A ceramic humidity sensor has advantages of both chemical and thermal stability; thus, many metal oxides such as $\mathrm{ZnCr}_{2} \mathrm{O}_{4} / \mathrm{LiZnVO}_{4}$ [12], niobia [13], $\mathrm{Al}_{2} \mathrm{O}_{3}-\mathrm{TiO}_{2}-\mathrm{SnO}_{2}$ [14] have been used as suitable materials. Needless to say, humidity-sensor materials should be insoluble in water, because they must be durable for adsorption/desorption cycles of water vapor. From this viewpoint, metal phosphate can be another candidate. Actually, hydroxyapatite [15], $\mathrm{AlPO}_{4}$ [16], and $\mathrm{Zr}\left(\mathrm{HPO}_{4}\right)_{2}[17,18]$ have been investigated as a ceramic humidity-sensing material. However, there still seems to be room for finding of other metal phosphates as a ceramic humidity-sensing material.

All metal phosphates were prepared by the methods given in the literature [19]. Sodium cation exchanged metal phosphates were also prepared [19]. Every precalcined sample was pulverized, pressed into a disc with $13 \mathrm{~mm}$ in diameter and $0.5-1 \mathrm{~mm}$ in thickness. Finally every disc was sintered at $800{ }^{\circ} \mathrm{C}$ for $3 \mathrm{~h}$ in air. An OS-type element was prepared by painting the comb-pattern electrodes shown in figure 7 on the one side of a disc with a silver paste and then by heating at $700^{\circ} \mathrm{C}$ for $10 \mathrm{~min}$. A sensor element was placed in a test chamber $(200 \mathrm{ml})$ containing a suitable saturated salt solution $(40 \mathrm{ml})$, which gives a specified relative humidity. The four-point resistance measurements of sensor elements were performed at $25^{\circ} \mathrm{C}$ by using a LCR meter (YHP4261A) under a applied voltage of $1 \mathrm{~V} \mathrm{AC}(1 \mathrm{kHz})$. 


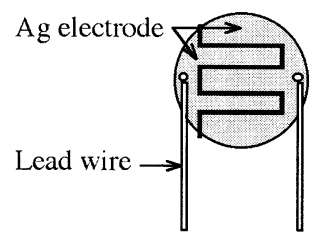

Figure 7: Schematic view of OS-type sensor element

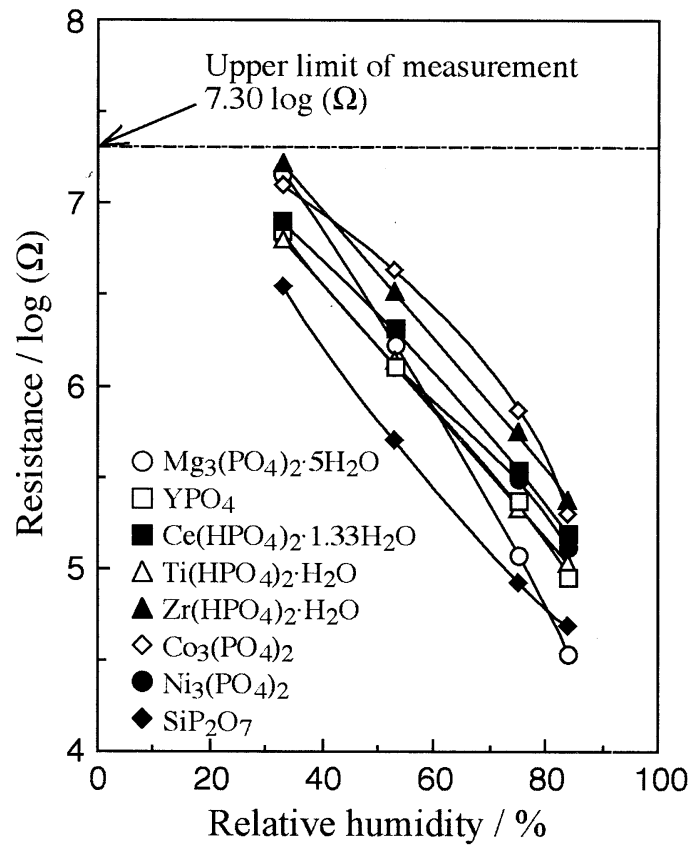

Figure 8: Humidity-sensitive characteristics of various metal phosphate elements

As can be seen in figure $8, \mathrm{Mg}_{3}\left(\mathrm{PO}_{4}\right)_{2} \cdot 5 \mathrm{H}_{2} \mathrm{O}, \mathrm{YPO}_{4}, \mathrm{Ce}\left(\mathrm{HPO}_{4}\right)_{2} \cdot 1.33 \mathrm{H}_{2} \mathrm{O}, \mathrm{Ti}\left(\mathrm{HPO}_{4}\right)_{2} \cdot 2 \mathrm{H}_{2} \mathrm{O}$, $\mathrm{Zr}\left(\mathrm{HPO}_{4}\right)_{2} \cdot 2 \mathrm{H}_{2} \mathrm{O}, \mathrm{Co}_{3}\left(\mathrm{PO}_{4}\right)_{2}, \mathrm{Ni}_{3}\left(\mathrm{PO}_{4}\right)_{2}$, and $\mathrm{SiP}_{2} \mathrm{O}_{7}$ showed good humidity-sensing characteristics; the electric resistance changed by two or three orders of magnitude in the humidity range 33 to $94 \%$ rh. Among them, $\mathrm{Mg}_{3}\left(\mathrm{PO}_{4}\right)_{2} \cdot 5 \mathrm{H}_{2} \mathrm{O}, \mathrm{SiP}_{2} \mathrm{O}_{7}$, and $\mathrm{Ti}\left(\mathrm{HPO}_{4}\right)_{2} \cdot 2 \mathrm{H}_{2} \mathrm{O}$ seem to be superior materials in terms of resistance variation with relative humidity and the linearity between resistance and relative humidity. As seen in figure $9, \mathrm{Zr}\left(\mathrm{HPO}_{4}\right)_{2} \cdot 2 \mathrm{H}_{2} \mathrm{O}$ showed better humidity-sensing characteristics than those of $\mathrm{Ca}_{10}\left(\mathrm{PO}_{4}\right)_{6}(\mathrm{OH})_{2}$ and $\mathrm{AlPO}_{4}$. In addition, it is noted that $\mathrm{Ce}\left(\mathrm{HPO}_{4}\right)_{2} \cdot 1.33 \mathrm{H}_{2} \mathrm{O}$ and $\mathrm{Ti}\left(\mathrm{HPO}_{4}\right)_{2} \cdot 2 \mathrm{H}_{2} \mathrm{O}$ exhibited similar humidity-sensing characteristics to those of $\mathrm{Zr}\left(\mathrm{HPO}_{4}\right)_{2} \cdot 2 \mathrm{H}_{2} \mathrm{O}$. 


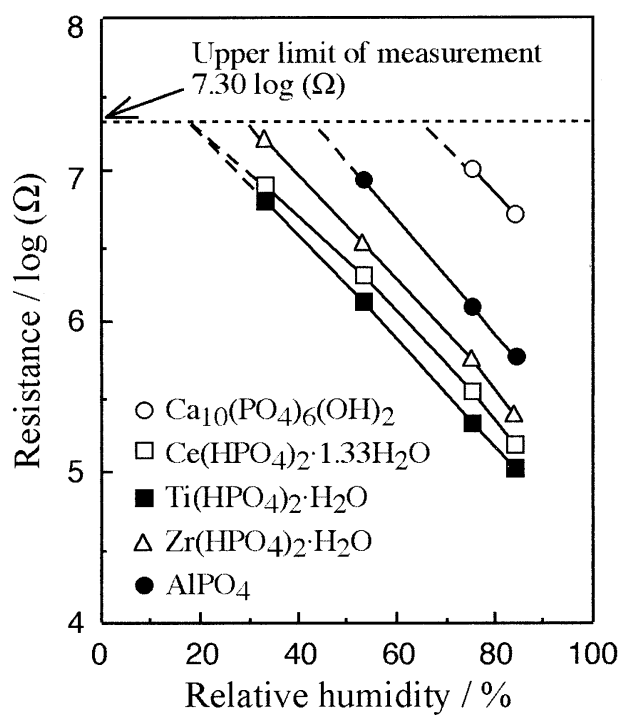

Figure 9: Humidity-sensitive characteristics of selected metal phosphate elements

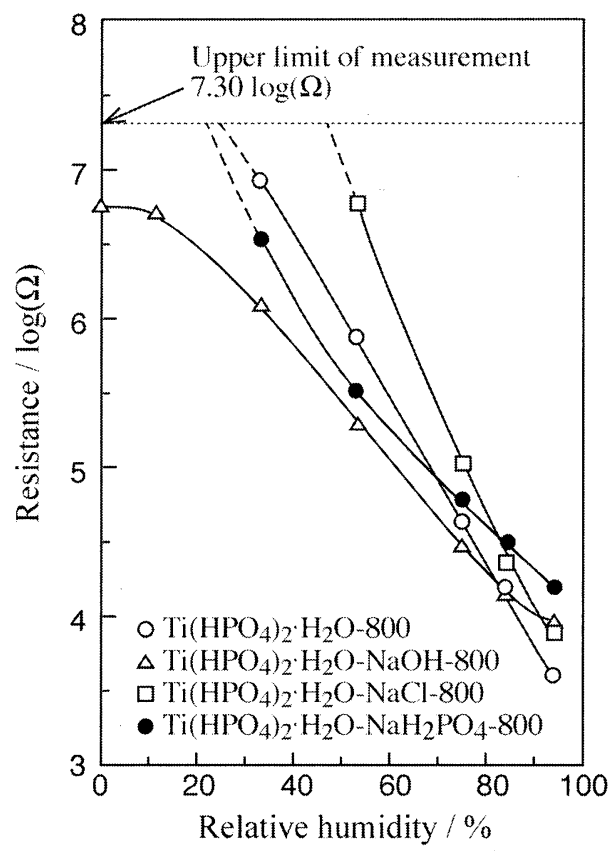

Figure 10: Humidity-sensitive characteristics of $\mathrm{Ti}\left(\mathrm{HPO}_{4}\right)_{2} \cdot \mathrm{H}_{2} \mathrm{O}$-based elements 
For a good humidity-sensitive characteristic, the resistance or conductance of the sensor must be low in a low relative humidity range. In the case of $\mathrm{Ti}\left(\mathrm{HPO}_{4}\right)_{2} \cdot 2 \mathrm{H}_{2} \mathrm{O}, \mathrm{NaOH}$-treatment made the resistance lower, especially in the middle relative humidity range. Contrary to these results, in $\mathrm{NaOH}$-treated $\mathrm{Ti}\left(\mathrm{HPO}_{4}\right)_{2} \cdot 2 \mathrm{H}_{2} \mathrm{O}$, considerably improved humidity-sensing characteristics were observed (Figure 10); the resistance decreased from $10^{6}$ to $10^{4}$ in the whole relative humidity range. The linearity was also improved greatly.

\section{Cu-P-Y-O Based Ceramic Humidity Sensor}

A variety of materials including several metal phosphates have been examined as humiditysensitive element. Among metal phosphates particular attention has been paid to zirconium phosphate [20-23]. Humidity sensors are based on variation in impedance or capacitance with the environmental humidity, and the impedance type is further divided into the two types, ionic and electronic [24]. The humidity sensor using zirconium phosphate can be grouped into the ionic type, because the impedance is inversely proportional to the concentration of the acidic hydrogen [20]. Some metal phosphates other than zirconium phosphate can be used as humiditysensing material, provided they have acidic property and can be molded into porous disc. Recently, we incidentally noticed that a composite compound containing $\mathrm{Cu}, \mathrm{P}$, and $\mathrm{Y}$ (denoted as $\mathrm{CPY}$ number, where the number indicates a $\mathrm{Cu} / \mathrm{Y}$ atomic ratio multiplied by ten) was produced by the solid-state reaction between $\mathrm{Cu}_{3}\left(\mathrm{PO}_{4}\right)_{2} \cdot 3 \mathrm{H}_{2} \mathrm{O}$ and $\mathrm{Y}_{2} \mathrm{O}_{3}$, and its resistivity was affected by the environmental humidity. A preliminary experiment revealed that the $\mathrm{CPY}$ involved $\mathrm{YPO}_{4}$ which had been known to exhibit weak surface acidity. Thus the CPY can be expected to have humiditysensitive property.

The CPY samples were prepared from calculated amounts of $\mathrm{Cu}_{3}\left(\mathrm{PO}_{4}\right)_{2} \cdot 3 \mathrm{H}_{2} \mathrm{O}$ and $\mathrm{Y}_{2} \mathrm{O}_{3}$ by the method given in the literature [25]. Figure 11 shows the schematic view of a sensor element, which was made by painting a silver paste on both faces of a disk-shaped sample and by heating at $700{ }^{\circ} \mathrm{C}$ for $10 \mathrm{~min}$. The resistance measurement of the sensor elements was performed in a manner similar to the experiment described above (3.1).

Figure 12 shows the humidity-sensitive characteristics of the CPY sensor elements prepared by sintering at $950^{\circ} \mathrm{C}$. Most of the CPY elements, except for the CPY-15 and CPY-20, showed lower resistivities, which decreased almost linearly with the increase in relative humidity. Among the sensor elements tested the CPY-10 or CPY-13 element is considered to be a promising sensor material for the wide resistivity change of three orders in magnitude over the whole range. Four kinds of crystalline phases $\mathrm{YPO}_{4}, \mathrm{Y}_{2} \mathrm{O}_{3}, \mathrm{CuO}$, and $\mathrm{Cu}_{2} \mathrm{Y}_{2} \mathrm{O}_{5}$ were observed in most $\mathrm{CPY}$ samples. $\mathrm{YPO}_{4}$ and $\mathrm{Y}_{2} \mathrm{O}_{3}$ elements exhibited comparable resistivity to that of the CPY-10 element, and $\mathrm{YPO}_{4}$ was found to play more important role in those elements. In addition, it was suggested that a critical point for the excellent humidity-sensitivity of the CPY-10 and CPY-13 elements at least in the lower relative humidity range will be the synergistic effect of $\mathrm{CuO}\left(\right.$ and/or $\left.\mathrm{Cu}_{2} \mathrm{O}\right)$ as an electronic conductor and $\mathrm{YPO}_{4}$ as an ionic conductor.

\section{CONCLUSION}

A number of useful surface-functional materials can be obtained from phosphates by finding means best fitted to make the most of their peculiar characteristics. 


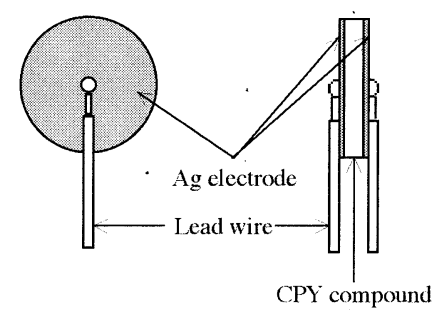

Figure 11: Schematic view of sensor element

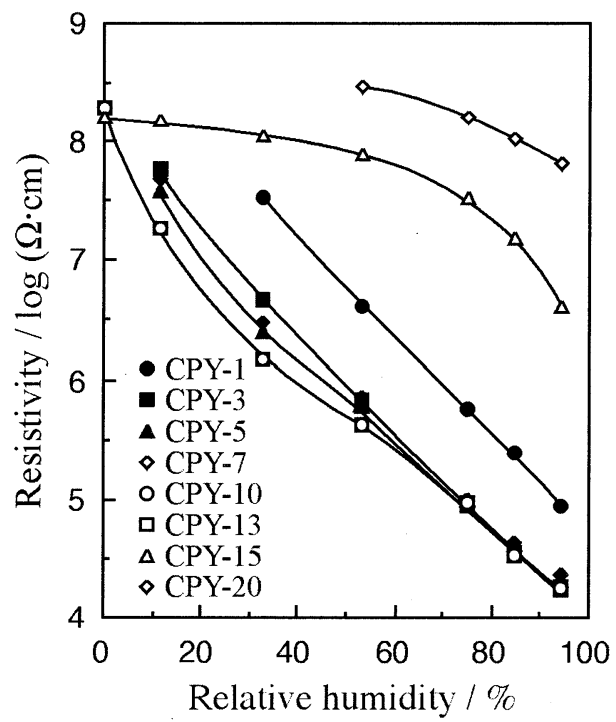

Figure 12: Humidity-sensitive characteristics of CPY compounds

\section{REFERENCES}

1. L. Schmerling, V. N. Ipatieff, in W. G. Frankenburg et al. (eds), Advances in Catalysis, Vol. 2, Academic Press, New York, 1950, p. 21.

2. Y. Imizu, S. Aoyama, H. Itoh, A. Tada, Chem. Lett., 1981, 1455.

3. T. Inui, J. Tarumoto, F. Okazumi, H. Matsuda, Chem. Express, 1 (1986), 49.

4. A. Tada, H. Suzuka, Y. Imizu, Chem. Lett., 1987, 423.

5. A. Tada, Proceedings of $9^{\text {th }}$ Annual Saudi-Japanese International Symposium, 1999, Session 4, p. 14.

6. A. Tada, N. Okazaki, M. Oishi, H. Itoh, Y. Imizu, Phosphorus Res. Bull., 3 (1993), 109.

7. M. Iwamoto and H. Yahiro, Catal. Today, 22 (1994), 5.

8. H. Hamada, Catal. Today, 22 (1994), 21-40.

9. N. Okazaki, S. Osada, and A. Tada, Appl. Surf. Sci., 121/122 (1997), 396-399. 
10. N. Okazaki, Y. Shiina, H. Itoh, A. Tada, and M. Iwamoto, Catal. Lett., 49 (1997), 169-174.

11. A. Tada, Materials Chem. Phys., 17 (1987), 145-159.

12. Y. Yokomizo, S. Uno, M. Harata, and H. Hiraki, Sens. Actuators, 4 (1983), 599.

13. H. Tsuiki, T. Shimanouchi, N. Takahashi, N. Kakuta, and A. Ueno, Chem. Lett., 1990, 1729.

14. H. Yagi and M. Nakata, J. Ceram. Soc. Jap., 100 (1992), 152.

15. K. Muto, Y. Komine, and T. Sawada, Denshi Tsuusin Gakkai Gijutu Hokoku, 80 (1980), 17.

16. K. Sugaya, J. Nanao, A. Sakurai, and K. Nomaki, Sensa Gijutu, 2 (1982), 63.

17. Y. Sadaoka, M Matsuguchi, Y. Sakai, S. Mitusi, J. Mater. Sci., 22 (1987), 2975.

18. Y. Sadaoka, M Matsuguchi, Y. Sakai, S. Mitusi, J. Mater. Sci., 23 (1988), 2666.

19. A. Tada, T. Tomura, O. Genroku, and N. Okazaki, Phosphorous Res. Bull., 4 (1994), 7-12.

20. Y. Sadaoka, M Matsuguchi, Y. Sakai, S. Mitusi, J. Mater. Sci., 22 (1987), 2975.

21. Y. Sadaoka, Y. Sakai, M Matsuguchi, Sens. Actuators, 13 (1988), 147.

22. Y. Sadaoka, M. Matsuguchi, Y. Sakai, S. Mitusi, J. Mater. Sci., 23 (1988), 2666.

23. Y. Sadaoka, Y. Sakai, M Matsuguchi, J. Mater. Sci., 24 (1989), 2081.

24. Y. Shimizu, H. Okada, H. Arai, J. Am. Ceram. Soc., 72 (1989), 436.

25. A. Tada, N. Okazaki, and H. Itoh, Phosphorous Res. Bull., 1 (1991), 227-232. 